\title{
The Haunting Presence of the Feminine: Virginia Woolf in the Streets of London
}

\author{
Agnieszka Pantuchowicz \\ SWPS University of Social Sciences and Humanities in Warsaw \\ apantuchowicz@swps.edu.pl
}

Received 31 March 2017; accepted 3 October 2017.

\begin{abstract}
Beginning with the theme of the location of haunting in Gothic interiors and the confusion of life and death and the "sub-central" positioning of the feminine as the hidden source of fearfulness, the paper analyzes Virginia Woolf's "Street Haunting: A London Adventure" as an example of a narrative written from the position of the haunting in which the figure of fearful feminine is transformed into a "hauntess" participating in the public world on equal rights with others. Woolf's text, though seemingly positing the protagonist in the position of flâneuse, in fact implicitly criticizes flâneuring as a masculine kind of looking and participating in the public space. Taking place away from home, Woolf's strolling in the streets of London carnivalizes (in the Bakhtinian sense) the activity by way of a joyful blurring of the split between the home and the market. Transgressing what Kathryn Simpson calls "the male privilege of the flâneur" (2010, p. 47) and rendering the transgression as haunting, Woolf evades participation in the masculine world of traffic and exchange by way of bringing the space of the Gothic confinement, and also of entombment, to the public.
\end{abstract}

Keywords: haunting; Gothicism; Virginia Woolf; gender; flâneur; market; London.

Gothic fiction seems to be a literary genre particularly predisposed to be read in the context of haunting as, very frequently, it is about haunting taking place in castles, villas, underground vaults, dungeons which usually constitute central places of action. According to Claire Kahane, "[I]n this dark, secret center of the Gothic structure, the boundaries of life and death themselves seem confused" (1985, p. 334). This confusion, the confusion of life and death, when projected upon human protagonists, results in various genres or species of living-dead haunting both the space of the novel and the readers. As Kahane convincingly argues, illustrating her arguments with Radcliffe's Mysteries of Udolpho, Lewis's The Monk, Shelley's Frankenstein and Austen' Northanger Abbey, hidden beneath the 
secret centre of the gothic is hidden space, a sub-centre of sorts which is "the spectral presence of a dead-undead mother, archaic and all encompassing, a ghost signifying the problematics of femininity" (1985, p. 334). Though the haunting living-dead in the story may be a man, a woman, or even an object (as is the case with the helmet in The Castle of Otranto), prompting this haunting, as it were, from beneath is a "dead-undead" woman, the womblike presence which is the reminder of the unity with the mother, of the presymbolic stage of life which might be called the stage of "nonseparation" in which "the Gothic fear is revealed as the fear of femaleness itself, perceived as threatening to one's wholeness, obliterating the very boundaries of self" (Kahane, 1985, p. 59). Interestingly, for Leona Sherman this nonseparation is a source of fear not only in The Mysteries of Udolpho, which she reads in her "Gothic Possibilities," but also in herself:

I find myself recreating from Gothic my ambivalence toward a femaleness which is my mother in me: nurturing and sexuality, mother and woman and child, conflicted between her and me and therefore in me as me. (Kahane, 1985, p. 338)

The Gothic structure, thus projected upon one's own life, translates life into a gothic story in which haunting is gendered as feminine and which threatens both men and women within whom the mothers cannot be fully repressed, a predicament whose seeming solution Freud found for men in the Oedipal complex, leaving women, as it were, to themselves.

According to Kahane, the mothers hidden in the traditional Gothic surface in the modern Gothic (for instance, in the fiction of Flannery O'Connor and Carson McCullers) which transforms the unseen into the seen, though at the cost of moving the Gothic towards the grotesque: we lose the obscurity of the traditional Gothic darkness which is replaced by the focus on distorted body images. These still haunt us, though the monstrosity of those who haunt seems to be a visibly aesthetic reaction to the grotesqueness of what we see. In both cases, however,

what is seen depends on how women are seen, but that in turn depends on our vision of the mother, a vision that in Gothic fiction is dominated by the uncanny mother of infancy, who will continue to haunt us as long as women remain, on the one hand, the sole custodians of infantile identity, and on the other, on the margin of social power. (Kahane, 1985, p. 351)

Having managed to escape from dark castles to the sphere of public visibility, the feminine is still perceived as grotesque, and its presence is still a haunting presence. This process of failed escape, of failed surfacing, has been aptly encapsulated by Bruno Schulz, whose travel to the foundations of the world in search of authentic beginnings of poetry and creation ends up with "the Mothers," a spectral and infernal space of the beginning of not so much life, as of stories:

We are here at the very bottom, in the dark foundation, among the Mothers. Here are the bottomless infernos, those hopeless Ossianic spaces, all those lamentable Nibelungs. Here are the great breeding grounds of history, factories of plots, hazy smoking rooms of fables and tales. (Schulz, 1979, p. 43) 
While histories, stories, fables and tales surface, "the Mothers" in Schulz's story remain at the foundations, thus Gothicizing the narratives. This haunting may frequently go unnoticed, but it lurks in the "deep structure" which is revealed not only by Gothic fiction, but also by psychoanalysis which in this respect carries a burden of Gothicism. Though Gothic novels can be, and frequently are, analyzed and interpreted in Freudian terms, Robert J. C. Young finds this "exercise" tautological because, as he claims, Freud's The Interpretation of Dreams of 1900 "was in fact a Gothic novel" (1999, p. 2), a story related "through the voice of a medical doctor" $(1999$, p. 12) whose inquiry turns out to be a revelation, or detection, of irrationality. In some stories this haunting of the unconscious may be repressed, but under a scrupulous reading it can always be revealed - to which a lot of psychoanalytic criticism clearly testifies. This revelation inevitably opens up a division into the haunting and the haunted, a division in which the latter are identifiable as "us," while the haunting are posited as them, the them, as in the case of Kahane, being gendered feminine. They are identifiable with "the uncanny mother of infancy," and they "will continue to haunt us." This "us" is thus inclusive of both men and women who, as haunted, would for some reason prefer not to identify with the haunting. This ungendered use of "us" posits an imaginary "general public" as haunted and in fact excludes the perspective of the haunting, silences the voice of the one who haunts. This story of the haunting is a rare kind of narrative. One recent example of such a text is Garrett Cook's $A$ God of Hungry Walls (2015). Though it seems that what haunts in the story is an old house, Cook himself in an interview with Ash Lomen deprives the haunting of even this provisional embodiment claiming that "haunting is bodiless and timeless and runs on its own propaganda" (Lomen, 2017). In Cook's story the haunted and the haunting are narrated in the first person singular by a haunted house which haunts from the position of an omnipotent god in whose power it is to control all feelings and thoughts of those who enter it. The story makes use of a typical model of the haunted interior, be it a house or a castle, the difference being that the voice is given to the haunting itself. This haunting, from the subjective position of the first person singular, expresses its pleasures and joys coming from a slightly sadistic desire to threaten and subject others who enter the house, whose interior functions in the story as the dominion of something which may be called a haunting in itself, a haunting for which the space of the house is but a fragile embodiment of the bodiless and timeless desire of exercising power over the domestic space.

The perspective of the haunting, however, may be quite different and the haunting may take place away from dark and mysterious Gothic interiors. Such a perspective is outlined in a narrative written from the position of an "outed" feminine, from the perspective of a woman who has surfaced from the Gothic dungeon into the public space of the streets of London in Virginia Woolf's essay titled "Street Haunting: A London Adventure" (1927). The word "haunting" appears only in the title of the essay and only once in Woolf's text which seemingly offers only a plain description of streets of London. "Haunting" appears in the last paragraph in which Woolf summarizes her visit to the city, claiming that "to escape is the greatest of pleasures; street haunting in winter the greatest of adventures" (2009, p. 187), thus also expressing the alleged experience of the haunter, of the one who haunts. What 
Woolf simultaneously performs in this sentence is a conflation of haunting with escape and adventure, actually with an escape from the room of one's own, which in the essay figures as a space of a claustrophobic kind of identity. Street haunting is, in fact, an experience of togetherness "after the solitude of one's own room" (p. 177), the room which three years later, in A Room of One's Own, would become the space of writing, of a kind of writing which is a means of escape. In "Street Haunting" the room of one's own is the space where "we sit surrounded by objects which perpetually express the oddity of our own temperaments and enforce the memories of our own experience" (p. 177). The homely interior is felt to be haunted by memories. In the room Woolf feels forced to be herself, confined to the oddity of herself which is, as it were, communicated by the haunting presence of the surrounding objects. The confinement to this kind of haunting, of the passive being haunted, is dissolved in the public space of the streets of London whose active haunting does not bring the pleasure of frightening others, but that of dissolving one's own identity, of becoming more than one, of becoming spectral rather than consolidated into a closed and walled unity created, or made, in the image of a room: "What greater delight and wonder can there be than to leave the straight lines of personality that one is not tethered to a single mind, but can put on briefly for a few minutes the bodies and minds of others" (p. 187).

Woolf's haunting is the feeling of becoming other, a brief and yet liberating experience which also opens up the closed identities of others. Being "tethered to a single mind" is metaphorically reminiscent of being tied to closed space, to a room to which others have no access, and from which there is no access to others. When in A Room of One's Own Woolf is not allowed to enter Cambridge's chapel and library reserved for men only, she thinks about the shut doors of the library in terms of pleasure and displeasure: "I thought how unpleasant it is to be locked out; and I thought how it is worse perhaps to be locked in," seeing in the masculine power of both locking out and locking in the source of "prosperity of the one sex and of the poverty and insecurity of the other" (Woolf, 2005, p. 24). Street haunting is a possibility of going out, but also that of going into the minds of others, where both the prosperous and the insecure become an "army of anonymous trampers" and where, importantly, the haunter loses her identity:

We are no longer quite ourselves. As we step out of the house on a fine evening between four and six, we shed the self our friends know us by and become part of that vast republican army of anonymous trampers, whose society is so agreeable after the solitude of one's own room. (Woolf, 2009, p. 177)

Beth Rigel Daugherty reads the London of Woolf's essay as a city of ghosts, the ghostliness consisting in people's not being themselves. In her reading, the city seems to be a joyful crowd of ghosts who do not really haunt anybody, because the division into the haunting and the haunted seems to be blurred:

Freed by being in public, the numerous people walking in London are accompanied by the ghosts of other selves, other identities. Woolf focuses on pleasure, irresponsibility even - the joy of the essay is apparent - as she traces the process of observation: the skimming of surfaces, the imagining of other people's inner worlds, and the entering of other people's social constructs. (2010, p. 191) 
Woolf's haunting is a joyful kind of activity which "carnivalesques" the city space. If Bakhtin located the practices of carnival in "a completely different, nonofficial, extraecclesiastical and extrapolitical aspect of the world, of man, and of human relations" (Bakhtin, 1984, p. 6), the space of Woolf's London is not only a scene of joyful dancing of the crowd away from institutions, but also a space which deconstructs the solidity of architecture, a space in which people are coming out of crannies rather than from homes in order to join others in the peculiar celebration of the everyday: "In what crevices and crannies, one might ask, did they lodge ... ?" (2009, p. 181). Even the dwarf she sees in a boot shop "had started a hobbling grotesque dance to which everybody in the street now conformed" (2009, p. 180). Though she herself is not singled out in the crowd, her haunting presence seems to be enchanting the street and suspending the laws of identity and, importantly, the laws of economy. At one point in the text the power of her gaze transforms everything she sees in Oxford Street into an unmarketable treasure:

Passing, glimpsing, everything seems accidentally but miraculously sprinkled with beauty, as if the tide of trade which deposits its burden so punctually and prosaically upon the shores of Oxford Street had this night cast up nothing but treasure. With no thought of buying, the eye is sportive and generous; it creates; it adorns; it enhances. (2009, p. 181)

The mechanism of this generous creativity, of the disinterested enhancement and enrichment of the world involves a peculiar change. Going out from the room, going haunting, involves a crucial transformation, a change from the geometrical squareness of a roomshaped identity into a monstrously enhanced organ of vision which Woolf describes as "a central oyster of perceptiveness, an enormous eye" (2009, p. 178). Though this eye seems to be an objective observer of surfaces, it sees, as it were, something different from what seems to be there. It is not an inquisitive eye, it does not look into things beyond their surface in search of truths or essences of things:

[A]fter all, we are only gliding smoothly on the surface. The eye is not a miner, not a diver, not a seeker after buried treasure. It floats us smoothly down a stream; resting, pausing, the brain sleeps perhaps as it looks. (2009, p. 178)

This description of the "enormous eye" seems to be that of an objective device seeing things as they are. What is thus revealed and celebrated is not only Bakhtin's "gay relativity of prevailing truths and authorities" (Bakhtin, 1984, p. 11) but also a world without the calculative reason, or brain, of economy which is replaced by pleasures coming not from appropriation, but rather from observation. This, along with the motif of walking in the city, is in obvious ways reminiscent of the Baudelaire-like figure of the flâneur, of the observerwalker in the metropolitan city, the figure which, as Ching-Fang Tseng notices, is frequently "considered the hero of modernism and an emblem of modernity" (2006, p. 223). The flâneur is what Michel de Certeau calls the "voyeurgod" who sees everything without being seen. He is also, as in the writings of Walter Benjamin, a master-collector of scattered images to be put together so as to evoke the feeling of mastery over the whole city. The flaneur in no way intervenes into the city environment which he observes and, importantly, positions himself between the home and the city space. What characterizes the flâneur is 
that, as Charles Baudelaire states, "in his cradle, a fairy has bestowed the love of masks and masquerading, the hate of home, and the passion for roaming" (Tseng, 2006, p. 234; emphasis added). Or, as Baudelaire puts it in "The Painter of the Modern Life," the desire of the flâneur is "[t]o be away from home and yet to feel at home anywhere, to be at the centre of the world, and yet to be unseen of the world" (Tseng, 2006, p. 223).

Reading Woolf's essay in the light of the idea of flâneuring, I will try to argue with Cheryl Hindrichs's claim that she "took up the tradition of the flâneur as a means of defamiliarizing our habitual narratives and institutions" (2009, p. 319). Rather, as I will try to show, her walk in the streets of London is subversive of the very division into public and private along with the roles assigned to the participants in both spheres. Thus, without going deeply into various and numerous theorizations of the flâneur figure, I will use it only as a counterpoint to the experience of haunting which speaks through Woolf's text.

Baudelaire's nineteenth-century flâneur walked in the city which was a masculine gendered sphere and in which the public presence of women was restricted. When in 1831 George Sand wanted to experience Paris life, she did it dressed as a boy:

So I had made for myself a redingote-guérite in heavy gray cloth, pants and vest to match. With a gray hat and large woollen cravat, I was a perfect first-year student. . . . It seemed to me that I could go round the world. And then, my clothes feared nothing. . . . No one knew me, no one looked at me, no one found fault with me; I was an atom lost in that immense crowd. (Wolff, 2004, p. 9)

What fascinated Sand was not what she saw, but her invisibility in the crowd which was also an illusion of independence. The disguise, as Janet Wolff observes, "made the life of the flâneur available to her; as she knew very well, she could not adopt the non-existent role of a flâneuse. Women could not stroll alone in the city" $(2004$, p. 9). It was only since the early decades of the twentieth century "that shopping has come to betoken for middleclass women the recently legitimized freedom of walking in the public spaces" (Tseng, 2006, p. 247). This new freedom was a freedom offered by such shopping spaces as arcades which, for Walter Benjamin, constituted a dual image of "house no less than street. Such an image is the prostitute-seller and sold in one" (2000, p. 10). The duality of this space does not simply translate the woman going out shopping into a flâneuse, a feminine version of the flaneur; it in fact constitutes a kind of threat to the flâneur's alleged independence and autonomy. Shopping poses a threat to the flâneur, Priscilla Ferguson notes, "because it severely undermines the posture of independence that affords the flaneur his occupation and his raison d'être" (1994, p. 27). A shopping woman, on the other hand, cannot be a flâneuse because doing shopping she is tied to the home, cares for it, and thus herself is split between two kinds of space, between the home and the market. Both these spaces “signify her husband's economic power" (Tseng, 2006, p. 235).

In "Street Haunting" shopping constitutes only a kind of excuse to go out: "[W]hen the desire comes upon us to go street rambling the pencil does for a pretext, and getting up we say: 'Really, I must buy a pencil'” (Woolf, 2009, p. 177). The pencil does not function simply as a desired commodity in the story, but develops a metaphorical association of 
haunting with writing, with writing as a pretext, or "pre-text," for going out of the room without a desire to appropriate the world, even to describe it. "Street Haunting" supplements the home with a spectral illumination of streetlights which is brought back to one's room along with the pencil, with the possibility of writing from within the room which thus becomes a room of one's own, a home independent of the masculine economic power. The essay ends with an unspoiled return from the haunting expedition whose trophy is almost nothing, a lead pencil described as a treasure:

Here again is the usual door; here the chair turned as we left it and the china bowl and the brown ring on the carpet. And here-let us examine it tenderly, let us touch it with reverence - is the only spoil we have retrieved from all the treasures of the city, a lead pencil. (Woolf, 2009, p. 187)

The pencil is not exactly an object of desire of the feminine walker in the essay. What she wants seems to be writing as a task and an effect of haunting, a haunting which, importantly, is not dreadful in the text. She easily identifies herself with both the inside and the outside, with me and not me, thus avoiding what Judith Butler calls in The Psychic Life of Power the refusal of identification governing the construction of masculinity which is "haunted by a dread of being what he wants" (1997, p. 137). This dread results in an imaginary mastering of what is, in fact, not wanted. There seems to be no dread in Woolf's haunting, and it is perhaps for this reason that using the word "haunting" in the title of the essay and embracing the inarticulacy of this "activity" she refuses to perform the repudiation of that inarticulacy, and this refusal itself may be seen as a refusal to articulate, or express sexuality. If gender, as Butler claims, "is composed of precisely what remains inarticulate in sexuality" (1997, p. 140), then the feminine haunting of the streets of London seems to be exactly an expression of this inarticulacy. The feminine haunting does not express a disguised wish, or desire, for the pleasures of strolling, or for flâneuring, as underlying this activity there is a highly articulate expression of separation from the world, of the pleasure of being independently sovereign. This sovereignty is also expressive of the superiority of the stroller over other, non-strolling creatures. In Louis Huart's Physiologie du Flâneur (1841) strolling was used as a defining feature of being human: "Man rises above all other animals only because he can stroll" (Pollentier, 2010, p. 20). Among the creatures excluded from the flânerie, Caroline Pollentier observes, are those who were excluded from the city in Aristotle's "political conception of the polis" which "has persistently been thought of as a distinctively human environment. Excluding slaves, women, animals, and all that is not man, the Aristotelian polis delimits the political sphere of citizenship" (2010, p. 20). Virginia Woolf in her short essay brings in a "politics of space" in which participation in the public sphere need not be divided and distributed in accordance with the gendered divisions of space into the public and the domestic. She evidently trespasses on what Simpson calls "the male privilege of the flâneur" (2010, p. 47), but the transgression, described as haunting, does not consist in participating in the masculine world of traffic and exchange, but in bringing the space of the Gothic confinement, and also of entombment, to the public. What Woolf's haunting also enables is what Susan 
Squier calls an "imaginative passage into many lives" achieved by stripping of "the defining and limiting possessions of the private home" (Squier, 1983, p. 494). This is done, moreover, in a slightly carnivalesque fashion, among the crowd and "the excesses of commodity display" (Simpson, 2010, p. 47). Woolf's haunting, through its feminine gendering, posits the marketplace of London as haunted not from the insides of its houses, but rather, paradoxically, from within the seeming exteriority and openness of the public space which turns out not to be immune to the spectrality of its own making, the spectrality effected through the haunting presence of the feminine gendered haunter in the space of the otherwise fair city of London.

\section{References}

Bakhtin, M. M. (1984). Rabelais and his world. (H. Iswolsky, Trans.). Bloomington: Indiana University Press.

Benjamin, W. (2000). The Arcades Project. (H. Eiland \& K. McLaughlin, Trans.). Cambridge, MA: Harvard University Press.

Butler, J. (1997). The psychic life of power: Theories in subjection. Stanford, CA: Stanford University Press.

Cook, G. (2015). A god of angry walls. Portland, OR: Deaddite Press.

Daugherty, B. R. (2010). The streets of London: Virginia Woolf's development of a pedagogical style. In E. F. Evans \& S. E. Cornish (Eds.), Woolf and the city (pp. 190-194). Liverpool, UK: Liverpool University Press.

Ferguson, P. P. (1994). The flâneur on and off the streets of Paris. In K. Tester (Ed.), The flâneur (pp. 22-42). New York, NY: Routledge.

Hindrichs, C. (2009). Feminist optics and avant-garde cinema: Germaine Dulac's "The Smiling Madame Beudet” and Virginia Woolf's "Street Haunting." Feminist Studies, 35(2), 294-322.

Holland, N., \& Sherman, L. (1976). Gothic possibilities. New Literary History, 8, $279-94$.

Kahane, C. (1985). The gothic mirror. In S. N. Gardner, C. Kahane, \& M. Sprengnether (Eds.), The (m)other tongue: Essays in feminist psychoanalytic interpretation (pp. 334-351). Ithaca, NY: Cornell University Press.

Lomen, A. (2017). Inside a god of haunted walls: An unconventional interview with Garrett Cook. Retrieved March 7, 2017 from https://yesclash.com/2017/01/12/inside-a-god-of-haunted-wallsan-unconventional-interview-with-garrett-cook/

Pollentier, C. (2010). Imagining flânerie beyond anthropocentrism: Virginia Woolf, the London archipelago, and city tortoises. In E. F. Evans \& S. E. Cornish (Eds.), Woolf and the city (pp. 20-30). Liverpool, UK: Liverpool University Press.

Schulz, B. (1979). The fictions of Bruno Schulz. (C. Wieniewska, Trans.). London, UK: Picador.

Simpson, K. (2010). "Street haunting," commodity culture, and the woman artist. In E. F. Evans \& S. E. Cornish (Eds.), Woolf and the city (pp. 47-54). Liverpool, UK: Liverpool University Press. 
Squier, S. (1983). "The London scene": Gender and class in Virginia Woolf's London. Twentieth Century Literature, 29(4), 488-500.

Tseng, C. (2006). The flâneur, the flâneuse, and the hostess: Virginia Woolf’s (un)domesticating flânerie in Mrs. Dalloway. Concentric: Literary and Cultural Studies, 32(1), 219-258.

Wolff, J. (2004). The invisible flâneuse: Women and the literature of modernity. In C. Jenks (Ed.), Urban culture: Critical concepts in literary and cultural studies, Vol.2 (pp. 3-16). London, UK: Routledge.

Woolf, V. (2009). Street haunting: A London adventure. In Selected essays (pp. 177-187). Oxford, UK: Oxford University Press. (Original work published 1927)

Woolf, V. (2005). A room of one's own. Orlando, FL: Harcourt. (Original work published 1929)

Young, R. J. C. (1999). Freud's secret: The Interpretation of Dreams was a Gothic novel. Retrieved January 21, 2017 from http://robertjcyoung.com/Freudssecret.pdf 